\title{
Pathological and parasitological characterization of infection by trematodes (Paramphistomatidae) in the large intestine of capybaras
}

Caracterização patológica e parasitológica da infecção por trematódeos (Paramphistomatidae) no intestino grosso de capivaras

Isabela de Oliveira Avelarr'; Ana Patrícia Carvalho Silva ${ }^{1}$; Chris Gardiner ${ }^{2}$;

Renato de Lima Santos ${ }^{1}$; Walter dos Santos Lima ${ }^{3}$; Roselene Ecco ${ }^{1 *}$

\author{
${ }^{1}$ Departamento de Clínica e Cirurgia Veterinárias, Escola de Veterinária, Universidade Federal de Minas Gerais - UFMG, \\ Belo Horizonte, MG, Brasil \\ ${ }^{2}$ Veterinary Pathology Service, Joint Pathology Center - JPC, Silver Springs, Maryland, USA \\ ${ }^{3}$ Departamento de Parasitologia, Instituto de Ciências Biológicas, Universidade Federal de Minas Gerais - UFMG, \\ Belo Horizonte, MG, Brasil
}

Received June 4, 2015

Accepted July 7, 2015

\begin{abstract}
Gross and histological lesions caused by an intestinal parasite were described in three capybaras. The parasites presented a mean length of $14 \mathrm{~mm}$ and width of $7 \mathrm{~mm}$, were round to oval or piriform, reddish and pedunculated, and adhered strongly to the mucosa of the large intestine. The intestinal mucosa at the parasite attachment site presented loss of surface epithelium and most glands, with replacement by fibrovascular proliferation that protruded from the mucosa and was involuted by the ventral sucker of the parasite. The lamina propria presented cellular debris, eosinophils, macrophages and plasma cells. The morphological characteristics, observed using serial histological sections, made it possible to classify the parasite as a trematode (Paramphistomatidae), compatible with Taxorchis schistocotyle. One capybara also harbored many ciliated protozoa in the large intestine (at the site of attachment of the parasite) and inside the caeca of the trematodes. In conclusion, this study described a multifocal necrotizing colitis associated with T. schistocotyle parasitism in capybaras.
\end{abstract}

Keywords: Wild animals, Taxorchis, capybara, trematode.

\section{Resumo}

Lesóes macroscópicas e histológicas causadas por um parasita intestinal foram descritas em três capivaras. Os parasitas apresentaram média de $14 \mathrm{~mm}$ de comprimento e $7 \mathrm{~mm}$ de largura, eram de circulares a ovais ou piriformes, avermelhados, pedunculados e estavam fortemente aderidos à mucosa do intestino grosso. A mucosa intestinal, em que os parasitas estavam aderidos, apresentou perda do epitélio e da maioria das glândulas, sendo substituídos por proliferação fibrovascular que se projetava a partir da mucosa e era envolvida pela ventosa ventral do parasita. A lâmina própria apresentou restos celulares, eosinófilos, macrófagos e plasmócitos. As características morfológicas, utilizando cortes histológicos seriados, proporcionaram a classificação do parasita como um trematoda Paramphistomatidae, compatível com Taxorchis schistocotyle. Uma capivara continha também numerosos protozoários ciliados no intestino grosso (no local de fixação do parasita) e no lúmen do ceco desses parasitos. Em síntese, este estudo demonstrou a ocorrência de colite necrótica associada ao parasitismo por T. schistocotyle em capivaras.

Palavras-chave: Animais selvagens, Taxorchis, capivara, trematoda.

\footnotetext{
*Corresponding author: Roselene Ecco. Laboratório de Patologia,

Departamento de Clínica e Cirurgia Veterinárias, Escola de Veterinária,

Universidade Federal de Minas Gerais - UFMG, Av. Antônio Carlos, 6627,

CEP 31270-901, Belo Horizonte, MG, Brasil. e-mail: eccoro.ufmg@gmail.com
} 


\section{Introduction}

Capybaras are herbivorous rodents of semiaquatic habits belonging to the order Rodentia, family Hydrochoeridae. The species occurs in South America, and the only subspecies found in Brazil is Hydrochoerus hydrochaeris hydrochaeris (BONUTI et al., 2002). Capybaras are socially and hierarchically organized into groups of approximately 20 animals with a dominant male, a few other males, several females, and juveniles. They eat plants, especially grasses in wetlands, and aquatic plants (LANGE \& SCHMIDT, 2007). The territory of the group is established in areas where they bathe, defecate and graze. The boundaries of the territory are usually not well defined, and fights between groups of capybaras often occur. In addition, struggles to define the hierarchy can occur when new groups are formed (JIMÉNEZ, 1995).

Capybaras are infected with several species of gastrointestinal helminths (BONUTI, 2002), but little is known about their biological and pathogenic characteristics. Among these helminths, Travassos et al. (1969) described trematodes that are considered to be capybara parasites, namely Taxorchis schistocotyle (FISCHOEDER, 1901). Other helminths described in capybara are: Hydrochoeristema cabrali (SINKOC et al., 2004), Hippocrepis hippocrepis (SINKOC et al., 2009), Nudacotyle valdevaginatus (TRAVASSOS, 1922), Nudacotyle tertius (TRAVASSOS, 1939) and Neocotyle neocotyle (TRAVASSOS, 1922).

This report describes the gross and histopathological findings, including the morphology, of a trematode in the family Paramphistomatidae that was found in the large intestine of three capybaras in the state of Minas Gerais, Brazil.

\section{Materials and Methods}

Two adult female capybaras (capybara 1 and 2) (Hydrochoerus hydrochaeris), were found dead on the shores of Pampulha lake (19 $51^{\circ} 44^{\prime \prime} \mathrm{S}$; $\left.43^{\circ} 58^{\prime} 14^{\prime \prime} \mathrm{W}\right)$, within the urban area of Belo Horizonte, state of Minas Gerais, Brazil, in 2007 and 2009. They were subjected to necropsy at the Veterinary School of the Universidade Federal de Minas Gerais. Tissue sections from the lungs, spleen, liver, brain, heart and intestine were collected, fixed by immersion in $10 \%$ buffered formalin, routinely processed and embedded in paraffin. Sections of thickness four micrometers were cut and stained with hematoxylin and eosin (HE). The third capybara (capybara 3) was an adult male that had been captured and killed by hunters in 2013, near the São Francisco River in the municipality

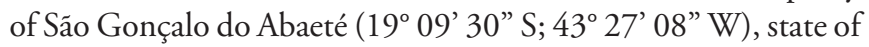
Minas Gerais, Brazil. Segments and contents of the large intestine (colon and caecum) were sent for examination, and tissue samples with parasites were collected, fixed in $10 \%$ buffered formalin and submitted to histopathological evaluation.

\section{Results}

Grossly, both female capybaras (1 and 2) had multiple lacerations on the skin that were presumably caused by bites. Capybara 1 had severe emaciation and dehydration. The most important change was observed in the large intestine. The caecum and colon presented diffusely hyperemic serosa, and the mucosa had areas covered by a fibrinous and pseudomembranous exudate with multiple petechiae. In the caecum, there were 12 reddish, round to oval pedunculated parasites that firmly adhered to the mucosa, measuring $14 \mathrm{~mm}$ long by $7 \mathrm{~mm}$ wide, on average (Figure 1). The most prominent lesion in capybara 2 was found in the caecum, which contained numerous parasitic structures that were morphologically similar to those found in capybara 1 (Figure 2). The mucosa of the large intestine, involving the colon and cecum, was moderately hyperemic and the serosa contained multifocal areas of linear hemorrhage measuring approximately $4 \times 1 \mathrm{~cm}$. The mesenteric lymph nodes of both capybaras were moderately enlarged due to cortical hyperplasia. Only tissue samples for histopathology were available in the case of capybara 3. About five to six parasites in each animal were separated for measurements, and were found to have average dimensions of $14 \mathrm{~mm}$ in length and $7 \mathrm{~mm}$ in width. The size of the parasites was similar in all three capybaras. Longitudinal sections through the parasite demonstrated that it adhered firmly to the mucosa by a ventral sucker, with projection of host mucosal granulation tissue into the sucker of the parasite (Figure 3a). In spite of these lesions, no specific clinical signs were observed.

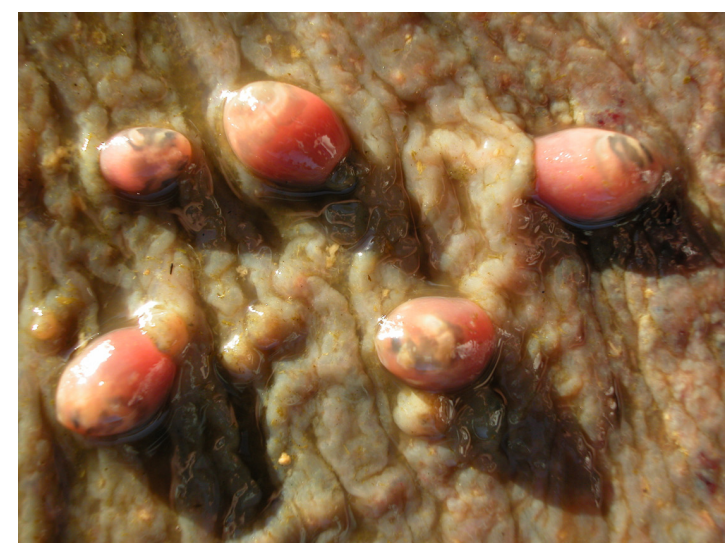

Figure 1. Capybara 1 with reddish, pedunculated and piriform parasites strongly adhering to the mucosa of the caecum.

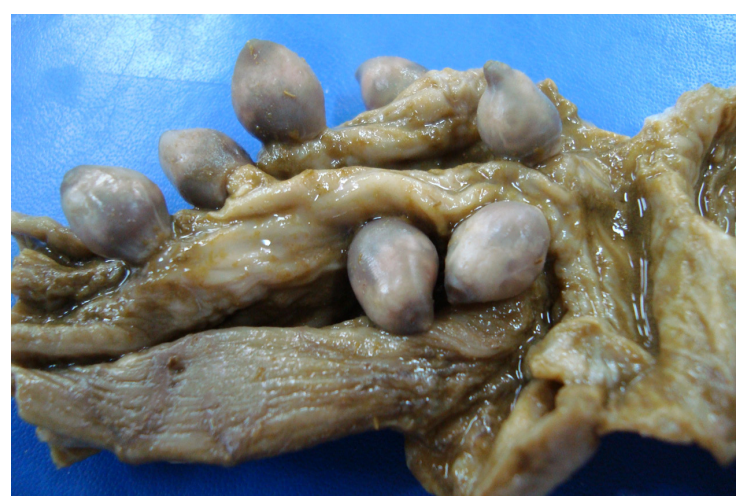

Figure 2. Mucosa of the caecum with several round to oval parasites, firmly adhering to the mucosa of capybara 2 . The picture was taken from samples fixed in $10 \%$ buffered formalin. 
Microscopically, the large intestine of capybara 1 showed marked diffuse acute fibrinonecrotic enteritis suggestive of bacterial enteritis. The pathological changes due to parasitism were similar in capybaras 1,2 and 3. The intestinal mucosa where the parasites were attached presented focal fibrovascular proliferation that protruded from the mucosa and was surrounded by the ventral sucker of the parasite. The site of attachment of the parasite showed complete loss of the luminal epithelium and also most of the cryptic epithelium, which was replaced by cellular debris, eosinophils, macrophages (some of which contained intracytoplasmic hemosiderin), plasma cells and fibrovascular proliferation in the lamina propria (Figure 3b). In some areas, this reaction was typical of granulation tissue, which was abundant in adult or larger parasites, thereby leading to compression and displacement of the internal structures of the parasites. The inflammatory infiltration extended to the adjacent mucosa and submucosa. Capybara 3 showed numerous ciliated protozoa in the lumen of the crypts and lamina propria (Figure 4). The tissues surrounding these protozoa were hyperemic and contained moderate numbers of eosinophils, lymphocytes and plasma cells. The organism ranged from $40 \mu \mathrm{m}$ to $60 \mu \mathrm{m}$ in diameter, with a large basophilic kidney-shaped macronucleus and numerous cilia on the surface. Some erythrocytes were observed in the cytoplasm of these protozoa.
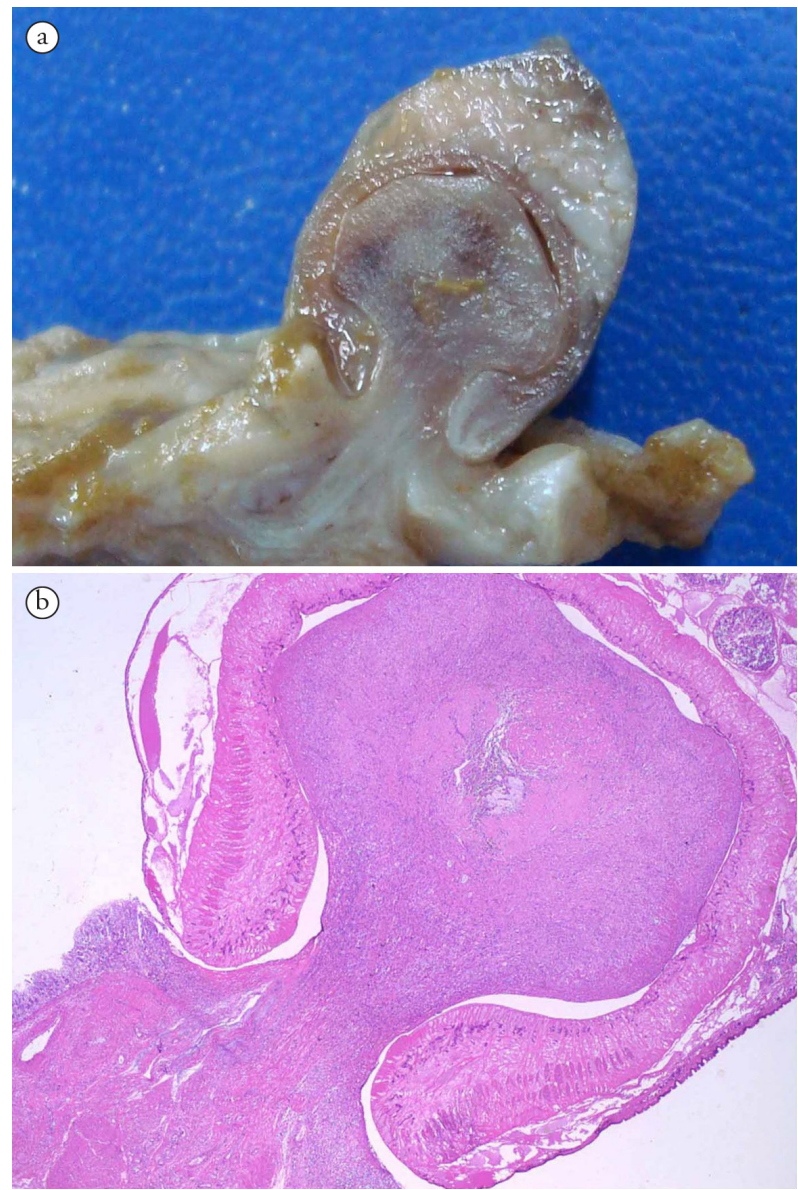

Figure 3. Capybara 2 a. Longitudinal section of parasite with projection of host tissue into the sucker of the parasite b. Parasite attached to the intestinal mucosa with ventral sucker and prominent fibrovascular proliferation and loss of the mucosa. HE. 2x.
The serial longitudinal histological sections of the parasites from all three capybaras had similar microscopic features. They were covered by an integument, with absence of a body cavity, and the organs were within a parenchymatous matrix. There were also an oral cavity of moderate size and a prominent ventral/posterior sucker, both with prominent muscles. The internal organs of the parasite included bilateral caeca, cirrus-sac, vitelline follicles, a uterus filled with eggs, testes and ovaries. Serial longitudinal sections were taken from three parasites of each animal to better observe the disposition of the organs. The tissue formed in the mucosa of the host protruded into the ventral sucker of the parasite and was responsible for compression and moderate displacement of the organs of the parasite. However, it could be observed that, below the oral cavity, there was a cirrus-sac presenting amorphous eosinophilic material in its interior, parallel caeca, a prominent central intercaecal uterus, vitelline follicles laterally extending to the ventral sucker and prominent testicles lateral to the uterus presenting branched small ovary near the ventral sucker (Figure 5). In the intestinal caeca of the parasites from capybara 3, several trophozoites of the ciliated protozoon were observed (Figure 6).

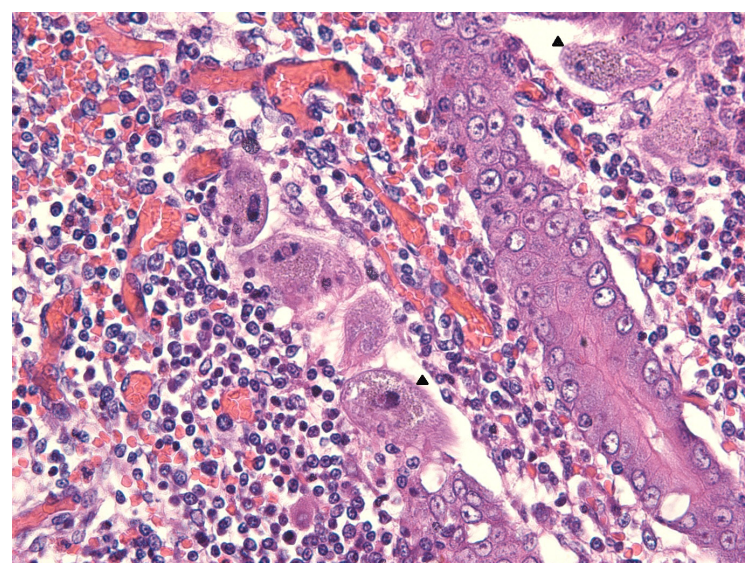

Figure 4. Mucosa of the caecum of capybara 3. There are some ciliated protozoa (arrows) hyperemia, haemorragiae, loss of epithelial cells, and moderate infiltrating by histiocytes and plasm cells. HE. 40x.

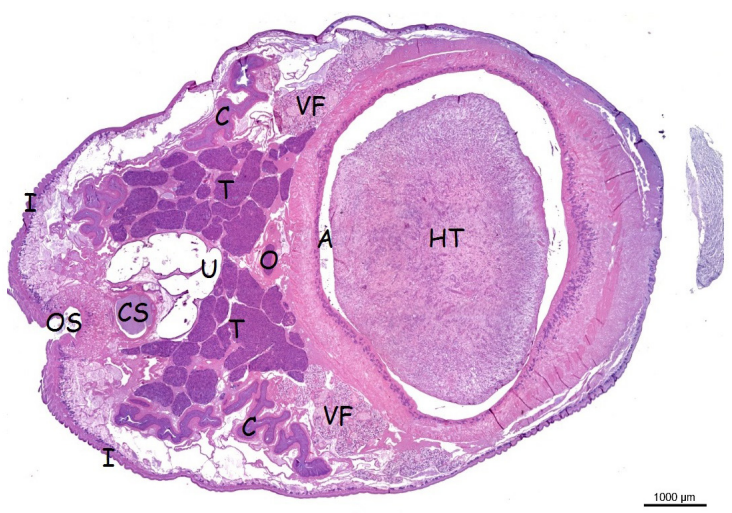

Figure 5. Longitudinal section through the parasite: (I) integument, (OS) oral sucker, (CS) cirrus-sac, (C) caeca, (U) uterus, (T) testes, (O) ovary, (VF) vitelline follicles, (A) acetabulum (or ventral sucker), (HT) host tissue. HE. 


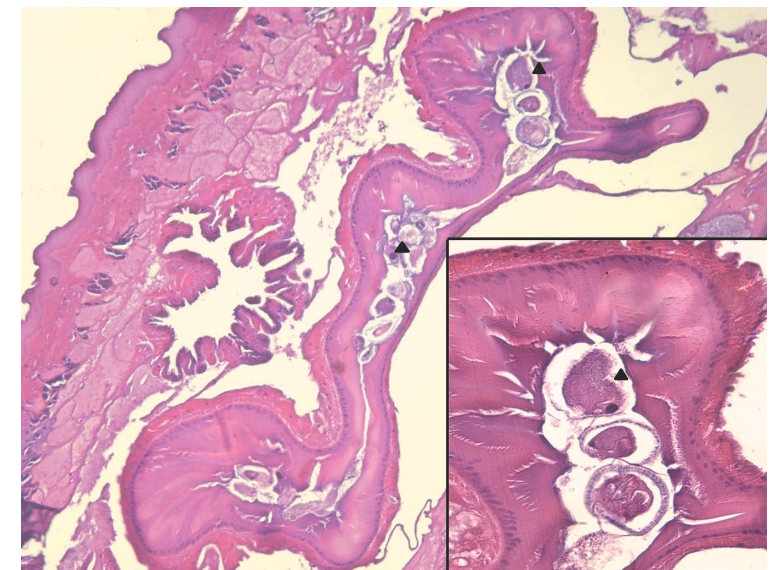

Figure 6. Longitudinal section through trematode from capybara 3. Inside caeca of this trematode, there are some ciliated protozoa (arrows). HE. 10x. Insert. HE. 40x.

\section{Discussion}

The parasitological and histological analysis enabled identification of the parasites found in the large intestine of these capybaras as trematodes belonging to the family Paramphistomatidae (subfamily Cladorchinae), classified as Taxorchis schistocotyle (FISCHOEDER, 1901). The trematodes from three capybaras had similar morphology, although capybara 3 was from a different geographic location. Morphologically, T. schistocotyle was described as having a large, robust, reddish and elongated body measuring $12.5 \mathrm{~mm}$ in length and $7.5 \mathrm{~mm}$ in width by Faust (1935) and, $14 \mathrm{~mm}$ by $6 \mathrm{~mm}$ by Añasco \& Martinez (2006), on average. Taxorchis schistocotyle was originally described as having well-developed body musculature and a ventroterminal sucker with a longitudinal opening and large muscle. The internal organs are constituted by long, large and slight sinuous caeca that terminate at the ovary or ventral sucker level; and a genital pore opening at the center of the genital sucker, which is located at the esophageal bifurcation or near to this. The cirrus-sac is present; the testes are lobed to branched in the middle third of the body; the ovary is spherical and located anteriorly to the ventral sucker; and there is an intercaecal uterus with numerous eggs and vitelline follicles located laterally to the caeca (TRAVASSOS et al., 1969; JONES, 2005). The morphology and positions of organs that have been described for $T$. schistocotyle are very similar to the findings from the parasites obtained from the three capybaras of this study.

This trematode was described for the first time in capybaras of the Panama Republic by Faust (1935). The genus Taxorchis was established in 1901 by Fischoeder and, later on, T. schistocotyle was described as an intestinal parasite of South American capybaras (Hydrochoerus hydrochaeris) (TRAVASSOS et al., 1969; JONES, 2005). Subsequently, another description using electron microscopy was made for this parasite from capybaras in Argentina (AÑASCO \& MARTINEZ, 2006). Taxorchis was described by Faust (1935) as a parasite that adheres to the peritoneal cavity, and by Añasco $\&$ Martinez (2006) as attached to the mucosa of the large intestine. In the present study, all three capybaras presented the parasite attached to the mucosa of the colon and caecum.
Some studies have reported gastrointestinal parasites in capybaras with the aim of studying the prevalence and intensity of infection caused by helminths in this species. The trematode T. schistocotyle has been found in the Taim Ecological Reserve, Rio Grande, state of Rio Grande do Sul, Brazil, with a frequency of 12.5\% (SINKOC et al., 2009); in Araçatuba, state of São Paulo, Brazil. with a frequency of $42.86 \%$ (SINKOC et al., 2004); in Venezuela with a frequency of $83 \%$ (SALAS \& HERRERA, 2004); in the Paiaguás region of the state of Mato Grosso do Sul, Brazil, with frequency and intensity of $76.6 \%$ and $18.2 \%$, respectively (BONUTI et al., 2002); in Bolivia with frequency of $12 \%$ (CASAS et al., 1995); and in Argentina with frequencies between 13 and 19\% (CORRIALE et al., 2013). However, no studies correlating any relationship between parasitism and the clinical signs, lesions and mortality were found.

Taxorchis schistocotyle feeds mainly on ciliates that exist in abundance in the caecum of capybaras. Helminths usually feed through a mechanism of exfoliation. They expropriate from the host organism a portion of the substance digested by the host for its own metabolism. This exfoliation does not cause great loss, except in the case of intense infestations (TRAVASSOS, 1950). In capybara 1 , the possible cause of death was bacterial enteritis and the parasites were incidental findings, since the quantity found was small and apparently not enough to determine the changes that had occurred that might explain the enteritis, diarrhea and death. In capybara 2, the infection was intense and there were no other changes that would explain its death. Capybara 3 was killed by hunters and the parasites were not counted. Nevertheless, curiously, many ciliated protozoa were observed particularly in the intestinal mucosa around the parasite and within the caeca of these trematodes (probably feed). To the best of our knowledge, this is the first report of a ciliated protozoan infection in intestinal trematodes, namely $T$. schistocotyle, in capybaras, although ciliated protozoa have previously been described in fecal samples from capybaras in Argentina (CORRIALE et al., 2011). Considering the morphology of these ciliated protozoa as well as their invasiveness of the intestinal mucosa, Balantidium sp. should be considered in the differential diagnosis.

The life cycle and the existence of intermediate hosts for T. schistocotyle are not well documented. Faust (1935) described the probable developmental stages of $T$. schistocotyle: the eggs laid by the adult parasites in the large intestine of the capybaras are eliminated through the feces to swampy ground, followed by maturation and hatching. The miracidia may then penetrate an appropriate molluscan host. Within the mollusc, the miracidia produce sporocysts, rediae and daughter rediae/cercariae, which emerge from the mollusc, swim through the water, crawl through the water grass, encyst and form metacercariae. Subsequently, they are consumed by capybaras. In the digestive tract of the mammal host, the metacercariae pass to the small intestine and reach the caeca, mature, become adults and lay their eggs.

In making the differential diagnosis, another trematode of the family Paramphistomatidae, called Hydrochoeristema cabrali, should be taken into consideration. Some details such as the length of the caeca, distribution of vitelline glands, large sucker muscles and dimensions (18 to $22 \mathrm{~cm}$ in length and 6.5 to $11 \mathrm{~cm}$ 
in width) allow differentiation between these two parasite species (SINKOC et al., 1998).

There is little information regarding the parasites of capybaras. Thus, to investigate the parasitic fauna of the digestive system of these animals is important, with particular attention to identifying helminth-induced lesions that may be directly related to weight loss and/or death. Based on this study, Hydrochoerus hydrochaeris is a potential host for Paramphistomatidae of the genus Taxorchis. Depending on the intensity of parasite infection, it may cause loss of the mucosa, thus contributing to the death of the animal.

\section{Acknowledgements}

Financial support for this study and fellowships were provided by the National Council for Scientific and Technological Development (Conselho Nacional de Desenvolvimento Científico e Tecnológico; $\mathrm{CNPq}$ ) and the Coordination Office for the Improvement of Higher Education Personnel (Coordenação de Aperfeiçoamento de Pessoal de Nível Superior; CAPES), Brazil. Protocol 21/2013 of the Ethics Committee for Animal Experimentation (CEUA/UFMG).

\section{References}

Añasco LG, Martínez FA. Breve descripción de Taxorchis schistocotyle Beddard, 1914 (Trematoda, Cladorchiidae) por microscopia electrónica de barrido. Parasitol Latinoam 2006; 61(3-4): 168-171.

Bonuti MR, Nascimento AA, Mapelli EB, Arantes IG. Helmintos gastrintestinais de capivaras (Hydrochoerus hydrochaeris) na sub-região de Paiaguás, Pantanal do Mato Grosso do Sul, Brasil. Semina: Ciênc Agrár 2002; 23(1): 57-62.

Casas MC, Zalles LM, Patrick MJ, Dailey M. Intestinal helminths of capybara (Hydrochaeris hydrochaeris) from Bolivia.J Helminthol Soc Wash 1995; 62(1): 87-88.

Corriale MJ, Milano AMF, Gómez-Muñoz MA, Herrera EA. Prevalence of gastrointestinal parasites in a natural population of capybaras, Hydrochoerus hydrochaeris, in Esteros del Iberá (Argentina). Rev Ibero-Latinam Parasitol 2011; 70(2): 189-196.

Corriale MJ, Orozco MM, Perez IJ. Parámetros poblacionales y estado sanitario de carpinchos (Hydrochoerus hydrochaeris) en lagunas artificiales de los esteros del Iberá. Mastozool Neotrop 2013; 20(1): 31-45.
Faust EC. Notes on helminths from Panama. I. Taxorchis schistocotyle (Fischoeder, 1901) from the Panamanian capybara, Hydrochoerus isthmius Goldman, 1912. J Parasitol 1935; 21(5): 323-331. http://dx.doi. org/10.2307/3271941.

Fischoeder F. Die Paramphistomiden der Säugethiere. Zoologischer Anzeiger 1901; 24: 367-375.

Jiménez EG. El capibara (Hydrochoerus hydrochaeris): estado actual de su producción. Roma: FAO; 1995.

Jones A. Family Cladorchiidae Fischoeder, 1901. In: Jones A, Bray RA, Gibson DI. Keys to the Trematoda. 1st ed. Wallingford: CABI Publishing; 2005. vol. 2. p. 257-318.

Lange RR, Schmidt EMS. Rodentia: roedores silvestres (capivara, cutia, paca, ouriço). In: Cubas ZS, Silva JCR, Catão-Dias JL. Tratado de animais selvagens. 1. ed. São Paulo: Roca; 2007. p. 475-491.

Salas V, Herrera EA. Intestinal helminths of capybaras, Hydrochoerus hydrochaeris, from Venezuela. Mem Inst Oswaldo Cruz 2004; 99(6): 563-566. http://dx.doi.org/10.1590/S0074-02762004000600004. PMid:15558163.

Sinkoc AL, Brum FA, Muller G, Brum JGW. Helmintos parasitos de capivara (Hydrochoerus hydrochaeris) na região de Araçatuba, São Paulo, Brasil. Arq Inst Biol 2004; 71(3): 329-333.

Sinkoc AL, Brum JGW, Muller G. Gastrintestinal helminths of capybara (Hydrochoerus hydrochaeris, Linnaeus, 1766) in cattle breeding farm in area of the Ecological Reserve of Taim, Rio Grande. Braz Arch Biol Technol 2009; 52(2): 327-333. http://dx.doi.org/10.1590/S1516-89132009000200009.

Sinkoc AL, Brum JGW, Müller G. Hydrochoeristrema cabrali sp. (Trematoda: Paramphistomatidae: Cladorchiini) parasito de capivara Hydrochoerus hydrochaeris Linnaeus, 1766 (Rodentia: Hydrochoeridae). Arq Inst Biol 1998; 65(1): 115-118.

Travassos L, Freitas JFT, Kohn A. Trematódeos do Brasil. Mem Inst Oswaldo Cruz 1969; 67: 1-886.

Travassos L. Contribuiçôes ao conhecimento de alguns trematódeos de Mato Grosso. Nudacotylinae Baker, 1916. Bol Biol 1939; 4: 160-167.

Travassos L. Informações sobre a fauna helminthológica de Mato Grosso. Folha Med 1922; 3: 187-190.

Travassos L. Introdução ao estudo da helmintologia. São Paulo: Instituto de Ciências Biomédicas; 1950. Retrieved in 7 August 2015, from http:// www.icb.usp.br/-cewinter/Travassos/ 